\title{
Perspektif Yaklaşımı ile Çalışma ve Depolama Alanında Hareket Takibi*
}

\author{
Kadir Hıdımoğlu ${ }^{11}$, Lale Özyllmaz ${ }^{2}$ \\ ${ }^{1}$ Yıldız Teknik Üniversitesi, Elektrik - Elektronik Fakültesi, Elektronik ve Haberleşme Mühendisliği Bölümü, Elektronik Doktora Öğrencisi, İstanbul, Türkiye \\ (ORCID: 0000-0002-2258-0224), kadirhidimoglu@hotmail.com \\ ${ }^{2}$ Yıldız Teknik Üniversitesi, Elektrik - Elektronik Fakültesi, Elektronik ve Haberleşme Mühendisliği Bölümü, Elektronik Dr. Öğr. Üyesi, İstanbul, Türkiye
} (ORCID: 0000-0001-9720-9852), ozyilmaz@yildiz.edu.tr

(İlk Geliş Tarihi 3 Eylül 2019 ve Kabul Tarihi 27 Eylül 2019)

(DOI: 10.31590/ejosat.614759)

*This article is produced from unpublished doctoral dissertation on "Human and Vehicle Analysis on Construction Site".

ATIF/REFERENCE: Hıdımoğlu, K. \& Özyılmaz, L. (2019). Perspektif Yaklaşımı ile Çalışma ve Depolama Alanında Hareket Takibi. Avrupa Bilim ve Teknoloji Dergisi, (17), 215-223.

\begin{abstract}
$\ddot{O} \mathbf{z}$
Çalışma sahasındaki iş güvenliği, yalnızca kazalar sonrası tedbirleri almak değil kazaya sebebiyet verecek durumların önceden belirlenerek önlemini almaya çalışmaktır. Görüntü işleme teknikleri, kayıtlı görüntüler veya anlık görüntüleri tekrar işleyerek istenilenler doğrultusunda yeniden görselleştirme işlemidir. Bu sebeple görüntü işleme teknikleri ile çalışma sahasında kaydedilmiş veya canlı görüntüler üzerinde iş̧̧ilerin ve diğer nesnelerin takibi yapılarak iş güvenliğini sağlamaya yönelik bir uygulama gerçekleştirilebilir. Gerçekleştirilmek istenilen amaç oluşabilecek iş kazalarının önüne büyük ölçüde geçmeye çalışmak aynı zamanda kişi ve araç analizi ile birden çok algoritma ve özelliğin kullanımını sağlamaktır. Çalışmada matematiksel algoritmaların yoğunluğu sebebiyle Matlab yazılım programı uygun görülmüştür. Bu yazıda yeni çift taraflı ve uyarlamalı perspektif yöntemlerinin eklenmesiyle bir hareket izleme algoritması uygulanmıştır. $\mathrm{Bu}$ yazının temel amacı, depolama ve inşaat alanlarındaki güvenlik sorunlarının çözülmesine yardımcı olacak bir hareket izleme algoritması önermektir. Önerilen algoritma ile şantiyede çalışan iş̧̧iler tespit edilir ve şantiyede güvenlik gereksinimlerine tamamen uygunluğu kontrol edilir. Detaylı algoritma açıklamaları makalenin metodoloji bölümünde bulunabilir. Canlı olarak alınan görüntü Matlab ortamında öncelikle filtreleme ve gürültü temizleme işlemleri gibi temel görüntü işleme teknikleri ile hazır hale getirilmiş ve sonrasında görüntüde hareket takibi için nesne bulma ve sınıflandırma işlemlerine tutulmuştur. Nesnenin düzgün bir şekilde bulunmasının ve takibinin ön işlmeler ile daha başarılı olduğu görülmektedir. Çalışılan ortamın 1şıklılık durumları ve hava koşulları ile hareketli veri yoğunluğu doğruluğu etkileyen önemli faktörlerdendir. İlk aşama olarak iş̧̧ilerin belirlenmesi basit sınıflandırma teknikleri kullanılarak yapılmıştır. Bu sınıflandırma kriterleri metodoloji bölümünde açıklanmıştır. Sınıflandırma işlemi dört adımda hareket takibi için insan veri kümesini sağlamıştır. Baret takmayan ya da yelek giymeyen ihlale sebep olan saha çalışanları "_" olarak tanımlanıp kurallara uyanlar "+" olarak görüntü üzerinde belirtilmiştir. Algoritmaların bu tip görüntüler üzerindeki performansı ve yapılan geliştirmeler sonucu son bölümde değerlendirilmiştir.
\end{abstract}

Anahtar Kelimeler: Görüntü işleme, Video işleme, Hareket takibi, Güvenlik, Çalışma sahası, Perspektif yaklaşımı.

\section{Motion Tracking in the Construction and Storage Area with Perspective Approach}

\begin{abstract}
Occupational safety in the work area is not only to take measures after accidents, but to try to take precaution by determining the situations that will cause the accident. Image processing techniques are the process of re-visualizing recorded images or snapshots according to the desired requirements. For this reason, by using image processing techniques, an application can be realized to ensure the safety of the work by following the workers and other objects on the recorded or live images in the worksite. The aim is to try to

\footnotetext{
${ }^{1}$ Corresponding Author: Yıldız Teknik Üniversitesi, Elektrik-Elektronik Fakültesi, Elektronik ve Haberleşme Mühendisliği Bölümü, Elektronik Doktora Öğrencisi, İstanbul, Türkiye, ORCID: 0000-0002-2258-0224, kadirhidimoglu@,hotmail.com
} 
avoid work accidents that may occur to a large extent and also to provide the use of multiple algorithms and features with person and vehicle analysis. In the study, the Matlab software program was deemed appropriate due to the density of mathematical algorithms.

In this paper a motion tracking algorithm with the addition of new double-sided and adaptive perspective methods have been implemented. The main purpose of this paper is to propose a motion tracking algorithm to help solving safety concerns at the storage and construction areas. With the proposed algorithm, workers on the work site are detected and they are checked if they comply with the safety requirements at the work site by using computers entirely. Detailed algorithm explanations can be found in the methodology part of the paper. The live image was prepared ready in Matlab environment by using basic image processing techniques such as filtering and noise cleaning processes and then it was subjected to object finding and classification for motion tracking in the image. Proper detection and tracking of the object seems to be more successful with preprocessing. Luminance conditions, weather conditions and moving data density are important factors that affect accuracy. As a first step, identification of workers was done using simple classification techniques. These classification criteria are explained in the methodology section. The classification process provided the human data set for motion tracking in four steps. Field workers who do not wear helmets or not wearing vests are defined as "-" and those who follow the rules are indicated as "+" on the image. The performance of the algorithms on this type of images and the results of the improvements are evaluated in the last section.

Keywords: Image processing, Video processing, Motion tracking, Safety, Construction site, Perspective approach.

\section{Introduction}

There are billions of people working in various works and workplaces and every job they have done and every brick they have put on the wall takes us forward. However; all these various works come down to one simple but important issue, safety. If a workplace cannot guarantee the safety of its workers or its customers, then the rest of the works has been done would be in vain. If the aviation industry didn't take the necessary steps after the disasters in the second half of the 20 th century, then flying would not be the safest transportation in the world. Therefore; in this work, we are addressing the safety issue in the construction and storage areas where the bigger machines operate and heavy materials are used. Any small mistake could easily cause catastrophic results in this type of workplaces and because of that, it is important to establish a surveillance system that is watching the work site. With advanced computational technology, it is known that a computer has the ability to administrate such a system. Therefore, having a worker in the surveillance system would be an ineffective use of resource management because it is not possible to maintain the focus that the computer has. Any small negligence by a worker could cause an injury or even the death of another worker in this kind of workplaces.

There are various uses of technology to do the job of mentioned safety observer. For example, depth sensors can be used to track the workers and machines or small chips which give warning in a hazardous situation can be used on the safety materials. However; we used a different method, image and video processing. There are also various methods which uses image and video processing; image and video processing with machine learning is one way of doing it for instance [1]. In machine learning, the workers and the machines can be taught to the system by using the past data. Some advanced image analysis techniques can be also used such a graph-cuts [2, 4] or active contours $[5,6]$. However, we use much simpler tactics. First of all, we use the advantage of the stationary camera. Since it is stationary, the only motion we can see throughout the video is workers and machines. Therefore; if we can determine all the stationary pixels, we can find the background image of the video. This image can be used to detect the workers and machines. Then, we use some features which are specific to the materials, workers, and machines to separate each one from another. After finding each separate object, we can observe if these objects comply with the regulations or not [7].

\section{Image Processing}

Before talking about the methodology, we provide some background information about images and image and video processing. The image-based image processing technique developed in parallel with today's requirements has taken a remarkable path. Existing and developing techniques and studies in the field of image processing have shown their effects in almost every field and have guided science and future studies. With these techniques, digital image data has been transformed into different forms suitable for the purpose or applied to obtain the data suitable for the need in the image. Medical and biology, geographic sciences, aerospace, defense industry, physics, arts, biomedical applications and security technologies are among the most important of these fields.

Image processing applications consist of a series of multiple processes, not one, depending on the needs. Many algorithms such as edge detection, object tracking, object recognition, feature extraction, motion detection and speed flow are applied to the digital image in accordance with the desired purpose after noise clearing, histogram equalization and filtering operations on the existing image data. In other words, image processing is a process different from "signal processing", which is the work of capturing and converting data after being measured and evaluated to another format or transferring it to another medium [8]. The digitized current image data is processed by the above-mentioned filtering, histogram equalization and noise clearance to create a clearer and more understandable set of operations than the existing data source before the algorithms. In the next step, image extraction and morphological processing and feature extraction and detection are performed. According to the feature information extracted in the last step, algorithms for segmentation and object recognition are performed in accordance with the purpose. 


\subsection{Image}

Digital images consists of small pixels. Each pixel has color information. When pixels form a 2-dimensional group of pixels or in other words a matrix, it is called an image. As the number of pixels is increasing, this would mean there is more information in the matrix resulting in a sharper image. The pixels have 2 main properties; radiometric property, and geometric property. The geometric property gives information about the pixel's location in the matrix. The radiometric property has information about the color of the image. In grey images, each pixel has a tone of grey $\mathrm{G}=(0,1,2, \ldots, 255)$ with 0 equal to black and 255 equal to white. If these images are shown in sequence with a small time difference between them, it would form an image sequence which is called a video.

\subsection{RGB Color Space}

We mentioned the radiometric property of the pixels and what does it mean in the grey image context. However, these pixels could also have other color information other than grey-tones. In this case, the color information is not taken from a single vector like in the case of grey images. Instead, there are 3 (1x256) vectors for each Red, Green and Blue tones. Red-only, green-only, and blue-only tones can be obtained from a single vector but to represent other colors, the mixture of these 3 vectors are used [9].

\subsection{Image Filters}

There are some transformation matrices that can change the shape of image matrices, also called as filters. These filters are generally used to obtain the desired images. For example; to get rid of image noise or to guess a hidden property of an image, filters are used.

\section{Methodology}

\subsection{Background Extraction}

As we have mentioned above, we use the advantage of stationary cameras. Since the stationary cameras are used, all of the pixels with the same geometric property in an image sequence would also have the same radiometric property. However, if some of those pixels contain information about a moving object, their radiometric values may differ. Since the movement happens faster, we would expect that the pixels' radiometric value to stay the same most of the time for pixels with the same geometric property and this value would give us the background image's radiometric value for the given geometric value. Thus, if we observe the behavior of pixels with the same geometric property in an image sequence, we can find the radiometric value of the corresponding background image's pixel. Doing this step for every geometric value would give the whole background image theoretically $[10,11]$. However, sometimes it may not be the case and a worker could stay where he is for a long time which can confuse the system. To overcome this, background extraction should not be measured over a short time period but the long time period.

We can denote the video pixels as a function of $\mathrm{u}, \mathrm{v}$ and $\mathrm{t}$;

$$
\text { pixel }=g(u, v, t)
$$

where $\mathrm{u}$ and $\mathrm{v}$ corresponds to the horizontal and vertical location of the image and $\mathrm{t}$ is time. We need to take sample image sequence between pre-determined time points, $t_{0}, t_{1}$

$$
\text { videosample }=\sum_{t=t_{0}}^{t_{1}} g(u, v, t)
$$

After taking the sample, we should look at every pixel sequence to determine which one is the most used or in other words background pixel. To do this calculation we can use a statistical mod for each pixel sequence in time. Then, we can construct the background image, $b(u, v)$ :

$$
b\left(u_{i}, v_{j}\right)=\bmod \left(g\left(u_{i}, v_{j}, t\right)\right)
$$

\subsection{Background Subtraction}

This step could be seen as a very straightforward subtraction but with a small mistake, the desired information could be deleted. If we subtract the image from one sample image from the video we would get another image which is meaningless to the eye. However, it contains the information we need.

After the subtraction, the image will have pixels with both high and low intensities. The higher ones will most likely belong to the moving objects but the problem is separating the lower ones. We used adaptive thresholding to overcome this problem. There are two conditions for a pixel to determine whether the pixel belongs to the moving object or the background. For a sample image $s(u, v)$ and the background image $b(u, v)$ the calculations is as follows:

$$
\begin{aligned}
& \text { dist }=\sqrt{\sum_{k=1}^{3} b\left(\left(u_{i}, v_{j}, k\right)-s\left(u_{i}, v_{j}, k\right)\right)^{2}} \\
& c 1=\text { dist }>\tau \sum_{k=1}^{3} b\left(u_{i}, v_{j}, k\right) \\
& c 2=\text { dist }>\tau_{0}
\end{aligned}
$$


Where $\tau_{0}$ is a static threshold and $\tau$ is an adaptive threshold. If both $\mathrm{c} 1$ and $\mathrm{c} 2$ are true, then it belongs to the moving object and if not, then the pixel belongs to the background. Thus we can obtain black and white or in other words binary image. Where the moving object's pixels are white and the background is black. Some small group of pixels may be thought to belong to the background inside the moving object. However, it is not a big problem since dilation and erosion filters can eliminate these small groups easily if the object is not entirely wrong.

\subsection{Classification of Moving Objects}

After obtaining the moving object with the methods mentioned above, the next step is separating the people or the workers from the machines and the materials. Since the shape of the people is very specific, several sub-methods related to the shape of the objects are used. Before explaining the methods, it should be noted that the objects are marked with rectangles.

1. The first method is to determine if the rectangle is big enough to represent a human. Some small objects can be eliminated easily with this method.

$$
c 1=\text { length }(\text { rectangle })>\tau_{2}
$$

$\tau_{2}$ is the size threshold. 1 is an example to show how this method works.

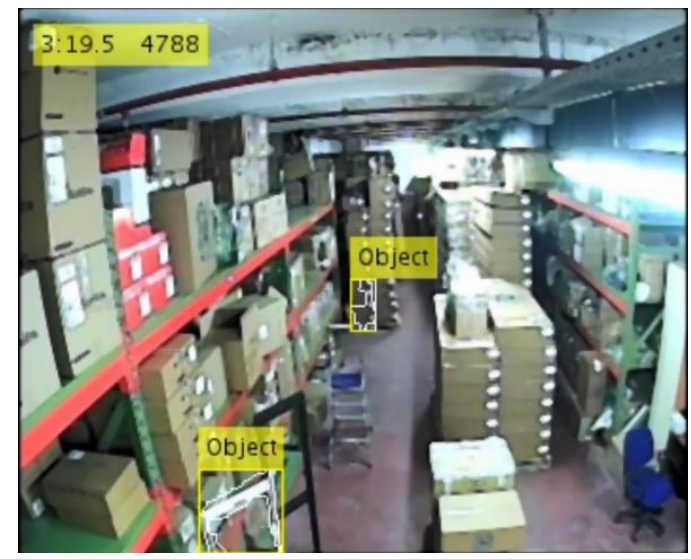

Figure 3.1. An example screenshot for size classification.

Depending on Figure3.1, object in the middle satisfy all the condition for it to be human; however, its size is below the threshold. Therefore it is classified as an object.

2. The second method is to determine if the aspect ratio is similar to a human's aspect ratio.

$$
\left.c 2=\tau_{3}>\text { height }(\text { rectangle }) / \text { width(rectangle }\right)>\tau_{4}
$$

$\tau_{3}$ is the higher and $\tau_{4}$ is the lower threshold. Since human's aspect ratio can neither be too large or too small, we use two threshold. 2 is an example to show how this method works.

3. The third method is looking at the rectangle's area and the object's area and comparing them. Since the shape of the human body is very close to a rectangle, both area should not be too different but some materials might be. We can also eliminate some materials with this method 3 is an example to show how this method works.

$$
c 3=\operatorname{area}(\text { object }) / \operatorname{area}(\text { rectangle })>\tau_{5}
$$

$\tau_{5}$ is the area ratio threshold.

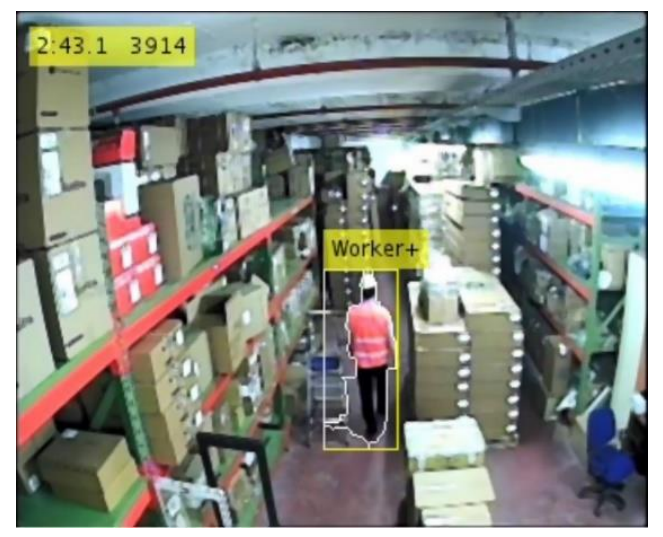

Figure 3.2. An example screenshot for aspect ratio classification. 
It can be seen from the Figure 3.2. that the proportion of the rectangle enclosing the human is inside threshold limits. Its height is longer than its width which we expect from a human.

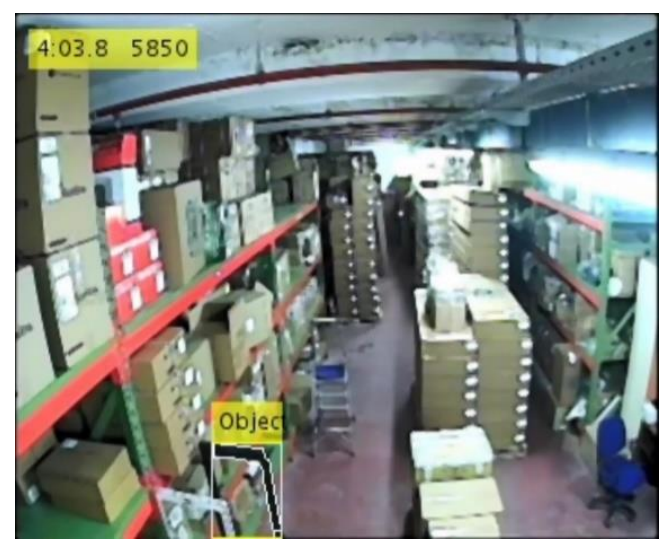

Figure 3.3. An example screenshot for area classification.

The object in the bottom of the Figure 3.3 is big enough to be human and its aspect ratio is also closer to the human's aspect ratio, longer height, shorter width. However, the object's area covers a small part of the rectangle. Therefore, it is classified as an object.

4. The fourth method is a little more complex. If we cut half the rectangle, the area ratio will be similar to the area ratio we found in the previous method. If we cut half the rectangle into rect1 and rect2, the algorithm will be as the following.

$$
\begin{aligned}
& c 4=\operatorname{area}(\text { object } 1) / \operatorname{area}(\text { rect } 1)>\tau_{5} \\
& c 5=\operatorname{area}(\text { object } 2) / \operatorname{area}(\text { rect } 2)>\tau_{5}
\end{aligned}
$$

The threshold is the same with the previous method 4 is an example to show how this method works.

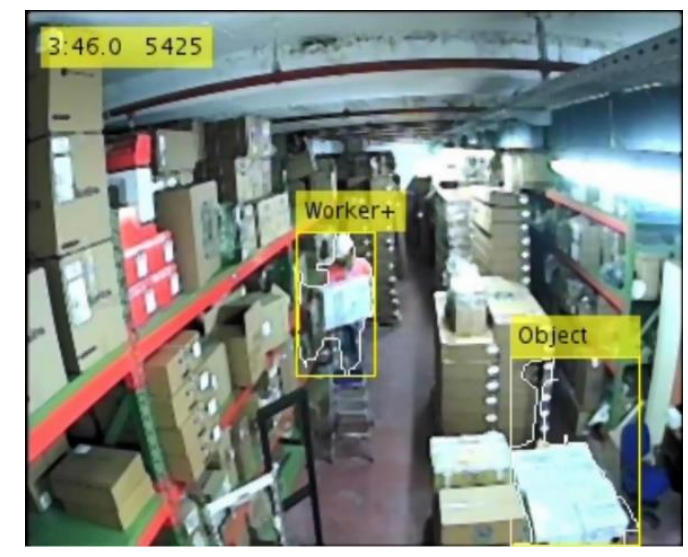

Figure 3.4. An example screenshot for double-sided area classification.

The object in the bottom right of the Figure 3.4 is big enough to be human and its aspect ratio is also closer to the human's aspect ratio, longer height, shorter width. Object's area also covers the significant portion of the rectangle. However, when we cut the rectangle into half and study the new smaller rectangles separately, it can be seen that one of the rectangles fails the test. Therefore, the object is classified as an object. Consequently, we have 5 conditions and if all of them are true, then the object in question is most likely a human or worker in our case.

\subsection{Safety of Workers}

After separating the workers from other objects, there are two main criteria which the workers are expected to comply. One of them is a safety helmet and the other one is a safety vest. These vests and helmets are created with distinct colors to make human eye detection easier. Fortunately, this is proved to be useful for the computational algorithm as well since it makes the detection easier.

Obviously, the helmets are in the head part of human and the vests are in the middle part. Thus; if the rectangle enclosing the worker is cut laterally to four pieces, it can be assumed that the helmets will be in the upper rectangle and the vests are in the middle two rectangles. For the head part, we can take the upper rectangle or rect1 into account. We can apply an RGB threshold to find the number of pixels which is the same color as the helmet. As we mentioned before, the color of the helmet is so distinct that the desired pixels can be found easily even with rough thresholding. If the number of pixels exceeds the pixel threshold that is determined beforehand, it can be assumed that the worker is wearing a helmet.

$$
\operatorname{Cij}=\sum i \sum j\left(\left(\operatorname{rect}(i, j, 1)>\tau_{6}\right) \times\left(\operatorname{rect}(i, j, 2)>\tau_{7}\right) \times\right.
$$




$$
\left.\times\left(\operatorname{rect}(i, j, 3)>\tau_{8}\right)\right)
$$

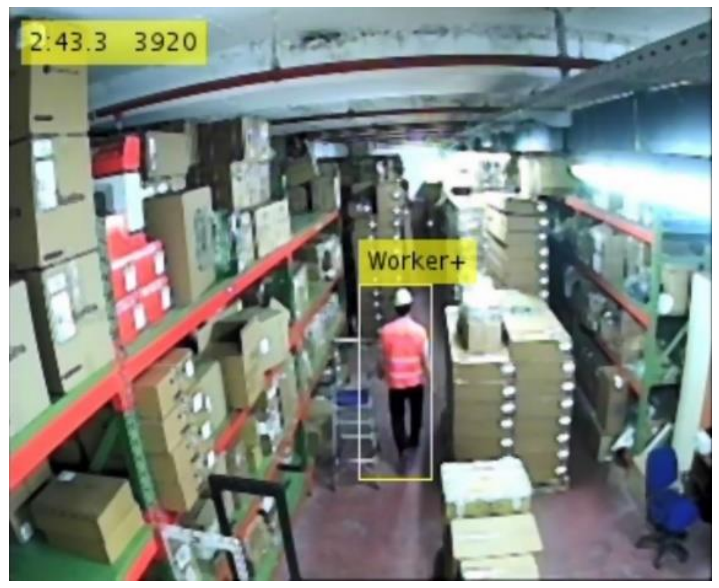

Figure 3.5. An example screenshot for helmet detection.

The white pixels exceed the threshold and hence the confirmation for a helmet on Figure 3.5.

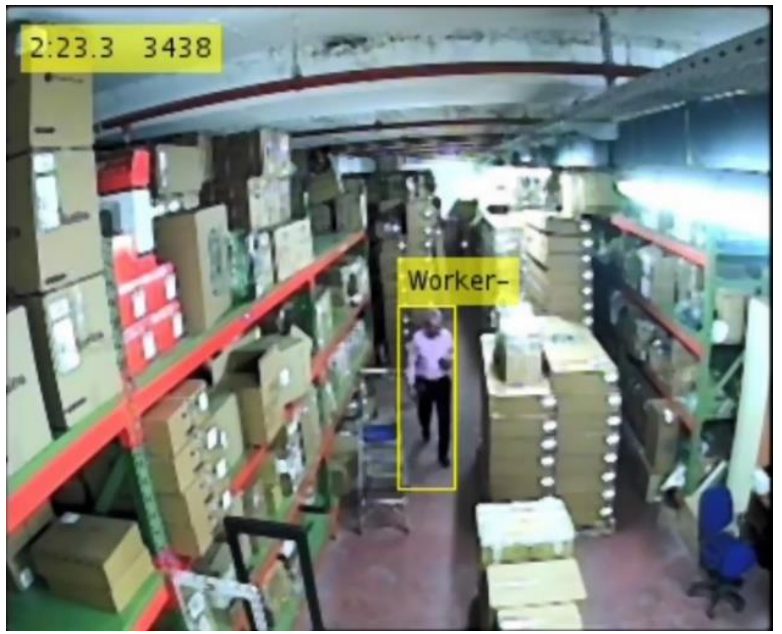

Figure 3.6. An example screenshot for helmet detection.

The white pixels cannot exceed the threshold and hence the confirmation for no helmet on Figure 3.6.

$\tau_{6}, \tau_{7}$ and $\tau_{8}$ are threshold values for red, green and blue respectively. If the number of true elements in the $\mathrm{C}$ matrix exceeds a certain threshold, we can assume that the worker is wearing a helmet. Figure 3.5 and 3.6 are examples to show how this method works.

The very same operation can be done but for the middle rectangles or in other words; rect2 and rect3. If the number of pixels exceeds a certain threshold, then we can assume that the worker is wearing a vest.

\subsection{Perspective Approach}

Another difficulty that we have encountered during the classification is the problems which stem from the collection of camera angle, size of the field and where the camera stands. When the moving object moves away from the camera its size which is perceived by the camera gets smaller. If the field is large enough, the worker who is moving away from the camera can be perceived as a small object and this may cause the worker to be classified as an object. This effect is widely known as perspective. Some sensitive thresholding may succeed when the in-question effect is in the formula but our aim is to increase the algorithm's robustness when the images get exposed to severe perspective effect. To overcome this difficulty we proposed two methods; double-sided perspective and adaptive perspective.

\subsubsection{Double-sided Perspective}

This method is more simple to understand and implement. To reduce the effect of perspective, the image is cut laterally into two separate images which can be named as closer image and distant image. Doing the same processes as they are done in the "Methodology" section would be enough. All classification methods except size thresholding are relying on the ratios but the size threshold is using the pixel count directly. Due to this, all thresholds but the size one can stay the same but the size threshold should be arranged such that it can detect the worker both in the distant and the closer images.

\subsubsection{Adaptive Perspective}


This method contains more computational complexity because we apply a different formula for every detected object unlike in the case of double-sided perspective which has only two different computation. In this method; for each object, a perspective coefficient is determined with the given formula:

$$
\rho=d \times \alpha
$$

where $\mathrm{d}$ is the distance between the object and the bottom of the image and $\alpha$ is a video coefficient which varies from video to video. When we multiply the perspective coefficient with the size threshold, we can find the adaptive size threshold for the given object.

$$
\tau_{\text {new }}=\tau_{\text {old }} \times \rho
$$

By using this size threshold for the corresponding object, it can be found out that if the object is fulfilling the size requirements to be classified as a worker.

\section{Results and Discussions}

\subsection{Results}

In this section, we presented the results we have found in our works using our algorithm both in storage and construction areas. There are three screenshots which are taken from three different videos (Figure 4.1, 4.2, 4.3). Three videos are recorded from storage rooms and one video is recorded from a construction site.

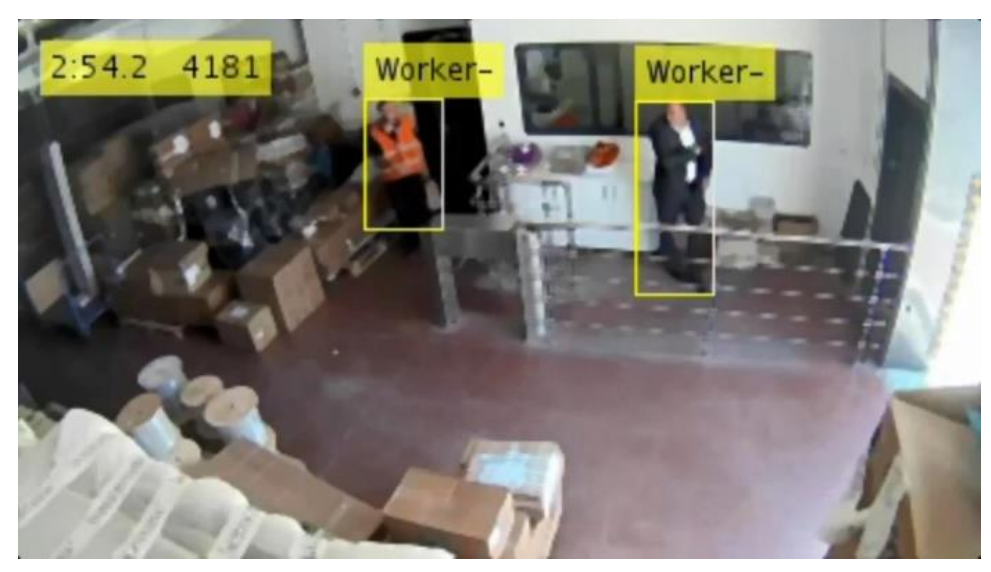

Figure 4.1. Result 1

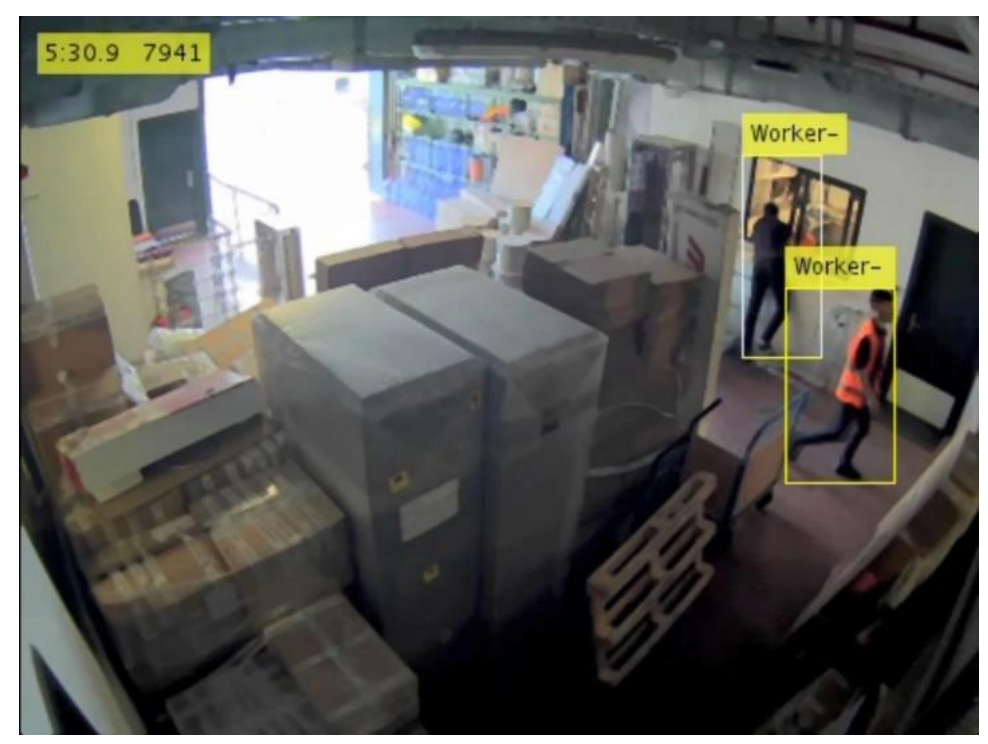

Figure 4.2. Result 2 


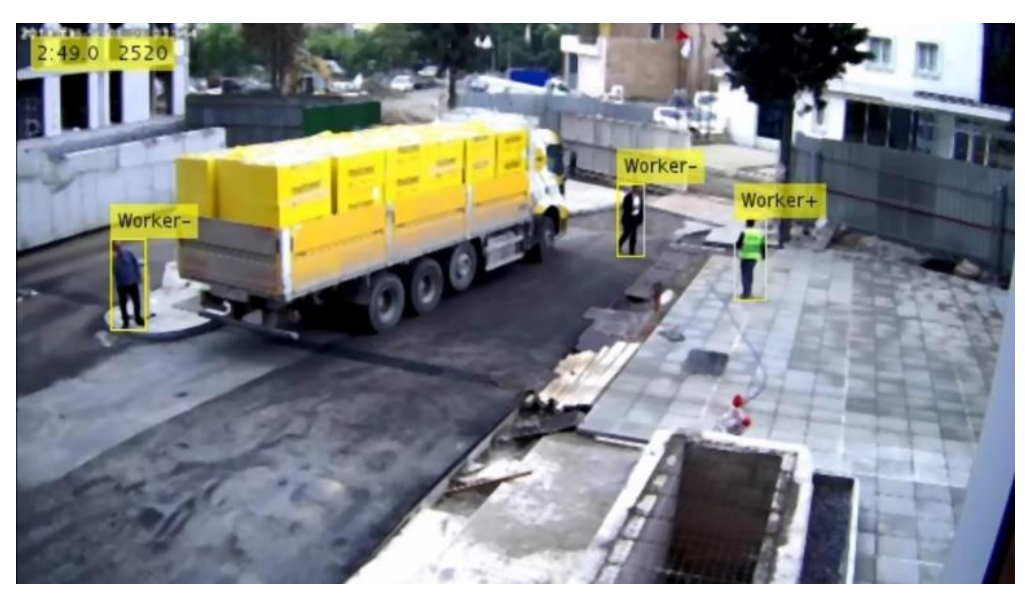

Figure 4.3. Result 3

Sometimes workers' clothes may blend with the background and cause those workers not to be detected or they may stay where they are with minimal movements which confuse algorithm and makes the worker a part of the background image. Some drastic and continuous weather changes also cause some problems since the background image is also changing with the weather. These problems can be overcome with dynamic background subtraction and calibration on site.

Additionally; when the distance between the camera and the worker is long, the algorithm may ignore the worker since the minimum area requirement. If we lower the threshold, this time small objects closer to the camera would exceed the minimum area threshold which causes the system to identify the object as a worker.

The number of occurrences of this problem is considerably high so the perspective method was very useful in that regard. However, the double-sided perspective was running well enough so the adaptive perspective method may not be necessary to use every time, especially when the relevant area is rather smaller. Furthermore; the workers may disappear from the scene momentarily because some requirements fail during a very small amount of time. Our optimization approach to this problem also works well and the interruptions happen rarely.

As a result, the proposed algorithm works as expected with some minor flaws. There were some major problems in the algorithm and they are resolved with our perspective and optimization approaches.

\subsection{Discussions}

In this part, the problems which occurred after the methodology will be discussed.

First of all, the detected humans may vanish for a period of time even though it has been detected before. This stems from the thresholding. Even though a rectangle satisfies all thresholds, one or two thresholds may fail moments after. To fix this it is obvious that the time-dependent solution is required. When the worker is detected, the system puts a mark to the detection location. Even the detection disappears, the big moving object can be detected by the system in the background. If this object is very similar to the detected worker's image a frame before, the system will deduce that the big object is still a worker even though it fails some thresholds. By the help of this algorithm, splits during the videos can be minimized.

Another problem that is encountered frequently is when a worker gets close to another worker and form a single and much bigger object. However, we already know each individual worker before and the system can detect a decrease in the number of workers. The decrease in number means that the worker either leaves the scene or forms a bigger object with another worker. By analyzing each workers before-location, it can be found that if the worker left the scene or not. If the disappearing worker was at the near of the edge of the image and no one was there, it is obvious that the worker left the scene. If the disappearing worker was next to another worker and disappear mysteriously, it can be deduced that the two workers form a single and bigger object and analyzing the new rectangle knowing there are two workers.

Algorithm 1 Algorithm Proposed in the Paper

1: Background image is extracted and subtracted

2: After subtraction erosion and dilation are applied

3: All object are enclosed with rectangles

4: 4 classification methods are applied to each objects at present using the perspective

5: Workers are detected

6: Safety requirements are controlled, checked if they are wearing safety equipment. 


\section{Acknowledgment}

I would like to thank to my esteemed jury members Prof. Dr. Tülay YILDIRIM, Asst. Prof. Dr. Arif DOLMA and Asst. Prof. Dr. Lale ÖZYILMAZ who guide me in the realization of the study with their thoughts.

\section{References}

[1] Jia X. Image recognition method based on deep learning, Chinese Control And Decision Conference 2017; 29: $4730-4735$.

[2] Shi J, Malik J. Normalized Cuts and Image Segmentation, IEE Transactions on Pattern Analysis and Machine Intelligence 2000; 8: 888-905.

[3] Wang S, Siskind J M. Image Segmentation with Ratio Cut, IEE Transactions on Pattern Analysis and Machine Intelligence 2003; 6: 675-690.

[4] Ford L, Fulkerson D. Flows in Networks. Princeton, NJ, USA: Princeton University Press, 2016.

[5] Kaas M, Witkin A, Terzopoulos W. Snakes - Active Contour Models. International Journal of Computer Vision 1987; 1: 321-331.

[6] Williams DJ, Shah M. A Fast Algorithm For Active Contours And Curvature Estimation. CVGIP: Image Under-standing 1992; 1: 14-26.

[7] Barbieri AL, de Arruda GF, Rodrigues FA, Bruno OM, Costa LdF. An entropy-based approach to automatic image segmentation of satellite images. Physica A: Statistical Mechanics and its Applications 2009; 3: 512-518.

[8] Gonzalez R. C., Woods R. E. (2007). Digital Image Processing, 3th Ed., (pp. 1-7), A.B.D., New Jersey : Prentice Hall.

[9] Yılmaz I. Renk Sistemleri, renk uzayları ve d“onu“sümler. In: Selçuk Üniversitesi Jeodezi ve Fotogrametri Mühendisliği O” gretiminde 30. Y1l Sempozyumu; 16-18 October 2002; Konya, Turkey; pp. 340-350.

[10] Cheung SS, Kamath C. Robust techniques for background subtraction in urban traffic video. ISandT/SPIE's Symposium on Electronic Imaging 2004; 18-22 January 2004; San Jose, CA, USA; pp. 881-892.

[11] Bobick A, Davis J. The Recognition of Human Movements Using Temporal Templates. IEEE Transactions on Pattern Analysis and Machine Intelligence 2001; 3: 257-267.

[12] Benezeth Y, Jodoin PM, Emile B, Laurent H, Rosenberger C. Review and evaluation of commonly-implemented background subtraction algorithms. In: 19th International Conference of Pattern Recognition 2008; 8-11 December 2008; Tampa, FL, USA: IEEE. pp. 192-199.

[13] Y1lmaz, A., Javed, O. ve Shah, M. (2006) Object tracking: A survey, ACM Comput. Surveys, 38(4), Article 13, 45p, doi: $10.1145 / 1177352.1177355$.

[14] Karasulu, B. (2010) Videolarda Hareketli Nesne Tespiti Ve Takibi İçin Benzetimli Tavlama Tabanlı Bir Başarım Eniyileme Yaklaşımı, (Doktora Tezi), Ege Üniversitesi Fen Bilimleri Enstitüsü, Bilgisayar Mühendisliği Anabilim Dalı.

[15] Benezeth, Y., Jodoin, P.M., Emile, B., Laurent, H. ve Rosenberger, C. (2008) Review and evaluation of commonly-implemented background subtraction algorithms, In: In 19th Int. Conf. of Pattern Recognition, (ICPR 2008), 1-4, doi: 10.1109/ICPR.2008.4760998. [16] Cheung, S.-C. ve Kamath, C. (2004) Robust techniques for background subtraction in urban traffic video, Video Communications and Image Processing, SPIE Electronic Imaging, San Jose, UCRL-JC-153846-ABS, UCRL-CONF-200706, 